\title{
ANALYSIS AND IMPROVEMENT OF THE GALVANIZED WIRE PRODUCTION PROCESS WITH THE USE OF DMAIC CYCLE
}

doi: 10.2478/cqpi-2019-0074

Date of submission of the article to the Editor: 18/04/2019

Date of acceptance of the article by the Editor: 13/05/2019

Krzysztof Knop ${ }^{1}$ - orcid id: 0000-0003-0842-9584

${ }^{1}$ Czestochowa University of Technology, Poland

\begin{abstract}
The article presents the results in the scope of analysis and improvement of the galvanized wire production process with the use of Six Sigma's DMAIC cycle. The basic problem was identified - incorrect wire diameters after galvanizing and specific tools and methods were used to analyze this problem and look for its solution. The potential of Pareto analysis, SPC method, control plan, 5WHY analysis was used. As a result of the analyzes carried out, the source cause was identified - contaminated containers dispensing the preparation maintaining the temperature in the galvanizing unit. To eliminate the problem, maintenance of the machine used to cover the bare wire with zinc was carried out, which allowed to achieve the following results: standstills at the Drawing and Galvanizing Department were eliminated, the duration of the manufacturing process and the percentage of products beyond the specification were significantly reduced.
\end{abstract}

Keywords: galvanized wire production process, Six Sigma, DMAIC, improvement

\section{INTRODUCTION}

The wires are divided into bare, galvanized, PVC coated, mechanical driving wires, welding wires and barbed and copper wires. Galvanized wire is one of the most commonly used materials, among others, on the construction site. It owes its unique properties to the proper treatment. Thanks to it, it meets high operational requirements - it is suitable for use in places where it is exposed to mechanical damage, chemical compounds and negative atmospheric factors. Galvanizing allows to protect the wire for many years requiring operation without the need for additional maintenance. Thanks to the zinc coating, it can give the wire additional aesthetic advantages using special varnishes or paints. The tested product is a soft galvanized wire with the symbol "Na" 3.0. The "Na" designation means low tensile strength of the wire below $50 \mathrm{kG} / \mathrm{mm}^{2}$ (approximately $490 \mathrm{MPa}$ ). This product meets the requirements of PN-67/M-80026 and related standards with a circular cross-section of $3 \mathrm{~mm}$ in diameter, made of general purpose low-alloy steel. The technology for producing such a wire is cold drawing. The wire produced is pulled through four strands of wire rod with a diameter of $6 \mathrm{~mm}$. The thickness of the zinc coating of the wire is determined using the Keller-Bohack method. 
For the tested product it should be $70 \mathrm{~g} / \mathrm{m}^{2}$. The surface of the galvanized wire itself should be smooth, without any uncoated areas.

The company under study is a producer of over five thousand assortment items, in groups of such products as: wires, nails, rods, fence nets, steel fibers. It is known on the domestic and foreign market. Galvanized wire accounts for over $58 \%$ of the production of finished products. The production volume of the metallurgical plant is over 32 thousand tonnes of finished products.

A picture of the tested product - galvanized wire together with the diameter requirements is shown in Fig. 1. Customers require that the diameter of the product is within the set limits of the dimensional tolerance. In this case, the tolerance indicated is 0.11 .

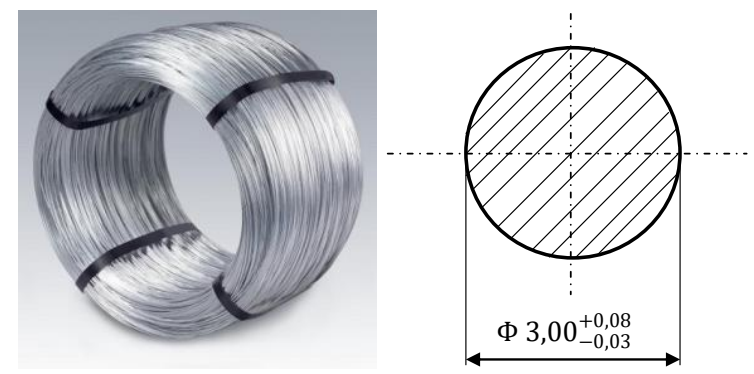

Fig. 1. View of galvanized wire with diameter requirements.

The aim of the work is to present the results in the improvement of the galvanized wire production process by limiting the main non-conformity of this product, i.e. exceeding the diameter deviations using the Six Sigma DMAIC cycle. To solve the problem, it should be analyzed thoroughly based on proven methodology and statistical data hence the choice of the DMAIC cycle as a path to solve the problem.

\section{METHODOLODGY OF THE RESEARCH}

In order to improve the production process of the galvanized wire, the Six Sigma DMAIC cycle was used. DMAIC is an acronym for Define, Measure, Analyze, Improve and Control (Basu and Wright, 2003) so contains 5 stages and differ from PDCA cycle (Jagusiak-Kocik, 2017; Chinvigai et al., 2007); is a methodology of process optimization, allowing an objective look at the problem and understanding it through the use of statistical analysis based on facts (Harry and Schroeder, 2005). DMAIC method is mainly based on the use of statistical process control, quality tools and process capacity analysis (Breyfogle, 1999). DMAIC is a systematic and orderly approach to solving the problem, allowing to thoroughly learn and understand its essence (Pande and Holpp, 2002). DMAIC solves problems related to defects or failures, deviation from the target, excessive cost or time (Pande et al., 2000). Identifies key requirements, results, tasks and standard tools for the project team to use to solve the problem (McCarty et al., 2005; Shankar, 2009). The best results from DMAIC are achieved when the process is flexible, thus eliminating unproductive steps (Sokovic et al., 2010).

The efforts undertaken as part of the DMAIC cycle focus on continuous improvement of processes in the organization in order to ensure full satisfaction of the client's requirements (Truscott, 2003). DMAIC is used for an existing product or process that is unable to meet customer needs, which distinguishes it from the DMADV cycle, which is used when a new product or process needs to be developed to meet customer requirements (Webber and Wallace, 2006). 
The DMAIC cycle was used to solve the problem identified, i.e. the wrong diameter of the galvanized wire. The scheme of application of the DMAIC cycle with the tools used is presented in Table 1.

Table 1

DMAIC cycle and applied methods and tools

\begin{tabular}{|l|l|l|}
\hline \multicolumn{1}{|c|}{$\begin{array}{c}\text { The name of the } \\
\text { stage }\end{array}$} & \multicolumn{1}{|c|}{ Description of procedure } & Methods and tools used \\
\hline Define & $\begin{array}{l}\text { Definition of the problem to be } \\
\text { analysed }\end{array}$ & $\begin{array}{l}\text { Pareto-Lorenzo diagram } \\
\text { Control plan }\end{array}$ \\
\hline Measure & $\begin{array}{l}\text { Measuring the process and } \\
\text { statistically analysing using control } \\
\text { charts and quality capability } \\
\text { indicators }\end{array}$ & $\begin{array}{l}\text { Control charts } \mathrm{xav}_{\mathrm{av}} \mathrm{-R}, \\
\text { capability indicators Cmp, } \\
\text { Cmkp }\end{array}$ \\
\hline Analyse & $\begin{array}{l}\text { Analyzing the causes of the } \\
\text { problem using descriptive tools }\end{array}$ & $\begin{array}{l}\text { Cause and effect tree, } \\
\text { 5WHY analysis }\end{array}$ \\
\hline Improve & $\begin{array}{l}\text { Take action to eliminate the } \\
\text { problem }\end{array}$ & $\begin{array}{l}\text { Corrective actions - } \\
\text { temporary and target }\end{array}$ \\
\hline Control & $\begin{array}{l}\text { Measurement of improvement. } \\
\text { Ensuring stability of the adopted } \\
\text { solutions }\end{array}$ & $\begin{array}{l}\text { Capability indicators Cmp, } \\
\text { Cmpk } \\
\text { Standardization }\end{array}$ \\
\hline
\end{tabular}

Source: own study

\section{RESULTS}

The results of using the DMAIC cycle to improve the production process of galvanized wire based on individual steps are presented:

\section{D - Define}

In the tested enterprise, a large number of non-conformity products emerged during the production of galvanized wire. It was decided to solve this problem. First of all, it was analyzed what kinds of non-conformities arise in the production of the tested product and which of these non-conformities prevails. Three months were accepted as a research period. The analysis of nonconformities was made using the Pareto-Lorenzo diagram (Dziuba et al., 2016; Dziuba et al., 2018). During the assumed research period, 10 nonconformities were identified in the galvanized wire production process: N1 - wire rod not in conformity with the metallurgical certificate, N2 - inadequate surface of bare wire (including dents, visible scratches or grease residues), N3 - incorrect surface of galvanized wire (smoothness with places not covered with zinc or excessive accumulation of zinc exceeding the wire dimensional tolerance), N4 - exceeding the deviations in the diameter of the galvanized wire, N5 - lack of adhesion of zinc coating (cracks and chipping after tests), N6 - incorrect thickness of zinc coating, N7 incompatible tensile strength and elongation, N8 - wire break after attempting to bend, N9 - the wrong appearance of the circle (tangled, twisted scrolls, connecting segments in a circle), N10 - improper packing (incompatible weight of the wire circle with its diameter, loose binding or strapping, peeling labels). Nonconformities marked with N1N10 symbols are presented according to the frequency of occurrence in the ParetoLorenz diagram (Fig. 1). 


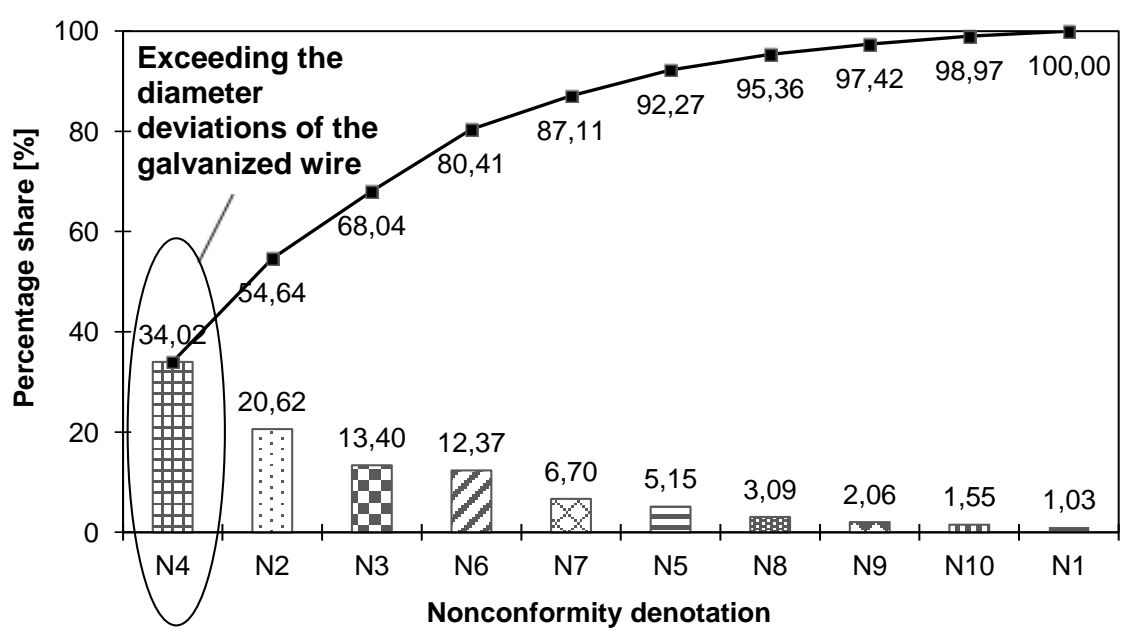

Fig. 1. Pareto-Lorenz diagram for the analysis of galvanized wire nonconformities

Based on the Pareto-Lorenz diagram, it was found that 2 out of 10 non-conformities $(20 \%)$, i.e. N4 (exceeding the diameter deviations of the galvanized wire) and N2 (inadequate bare wire area), result in $54.64 \%$ of all nonconformities in the galvanized wire production process with the symbol "Na" and diameter $3 \mathrm{~mm}$. Dimensional tolerance has the greatest influence on the quality of the wire. The most common nonconformity was a dimensional nonconformity of the wire $(34.02 \%)$, so it was decided to try to limit its share.

It was decided to refer to the control plan first, to link the dimensional non-conformity with the type of process, determine the process characteristics affecting the tested product feature - wire diameter, indicate the type of quality control used to detect a given nonconformity and identify the operator's reaction method to the existing one nonconformity. The result of this analysis in the form of the control plan is presented in the table 1.

Table 1

Fragment of the control plan for the process of pulling the wire and winding it on the spools and the galvanizing process of the wire to control the characteristics of the wire - diameter

\begin{tabular}{|c|c|c|c|c|c|c|c|c|c|c|c|}
\hline \multicolumn{12}{|c|}{ CONTROL PLAN } \\
\hline \multirow[b]{2}{*}{ 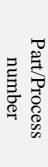 } & \multirow[b]{2}{*}{ 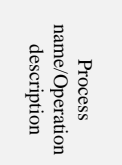 } & \multirow{2}{*}{ 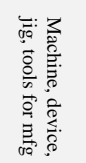 } & \multicolumn{2}{|c|}{ Characteristics } & \multirow[b]{2}{*}{$\overbrace{0}^{\Omega}$} & \multicolumn{5}{|c|}{ Method } & \multirow[b]{2}{*}{ 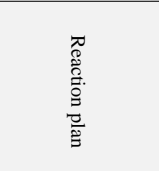 } \\
\hline & & & 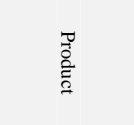 & $\begin{array}{l}7 \\
\overrightarrow{0} \\
0 \\
0 \\
\vdots \\
\vdots\end{array}$ & & 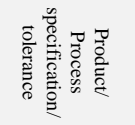 & 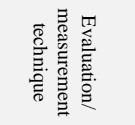 & 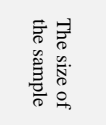 & 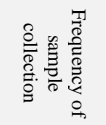 & 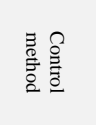 & \\
\hline 14 & $\begin{array}{l}\text { Drawing the } \\
\text { wire and } \\
\text { winding it on } \\
\text { the spools }\end{array}$ & $\begin{array}{l}\mathrm{KB} 4 / \\
600 \\
\text { drawing } \\
\text { machine }\end{array}$ & \multirow[t]{2}{*}{$\begin{array}{l}\text { The diameter } \\
\text { of the wire }\end{array}$} & $\begin{array}{l}\text { Parameters } \\
\text { of the cutting } \\
\text { tool and the } \\
\text { level of purity } \\
\text { of the drawer }\end{array}$ & \multirow[t]{2}{*}{$\mathrm{N}$} & \multirow[t]{2}{*}{$\begin{array}{c}\text { Nominal } \\
\text { diameter } \\
3 \mathrm{~mm}(+0,08, \\
-\mathbf{0 , 0 3 )}\end{array}$} & \multirow{2}{*}{$\begin{array}{c}\text { Manual } \\
\text { measurement } \\
\text { with a } \\
\text { micrometer } \\
\text { with an } \\
\text { accuracy of } \\
0.01 \mathrm{~mm}\end{array}$} & \multirow[t]{2}{*}{$\begin{array}{c}\text { A piece of } \\
\text { wire from } \\
\text { a circle } \\
\text { min. } \\
\text { length } 2 \mathrm{~m}\end{array}$} & \multirow[t]{2}{*}{$\begin{array}{c}\text { Once per } \\
\text { work shift }\end{array}$} & \multirow[t]{2}{*}{$\begin{array}{l}\text { Random } \\
\text { sampling }\end{array}$} & \multirow[t]{2}{*}{$\begin{array}{l}\text { Reclassifying } \\
\text { vertebrae or } \\
\text { repeating the } \\
\text { drawing process }\end{array}$} \\
\hline 24 & $\begin{array}{c}\text { Galvanizing } \\
\text { the wire in a } \\
\text { galvanizing } \\
\text { bath }\end{array}$ & $\begin{array}{c}\text { Zinc } \\
\text { aggregat } \\
\text { e }\end{array}$ & & $\begin{array}{c}\text { Maintenance } \\
\text { of the } \\
\text { galvanizing } \\
\text { unit }\end{array}$ & & & & & & & \\
\hline
\end{tabular}

The processes under which the controlled characteristics are the diameter of the wire is the wire drawing process and the wire galvanizing process. Such parameters of the process as parameters of the drawing tool and the degree of cleanliness of the drawing machine influence the value of the wire diameter after the drawing process, while the maintenance of the zinc unit - in the process of zinc plating the wire. The wire diameter is checked by taking a wire fragment from the coil at least $2 \mathrm{~m}$ long once per shift. The 
inspection is performed using a micrometer with an accuracy of $0.01 \mathrm{~mm}$. In the case of detection of non-conform wire diameter, the coils are reclassified or the drawing or galvanizing process is repeated.

The tests carried out on the samples taken from both processes showed that the problem with the wrong wire diameter involved mainly the samples taken after the galvanizing process. It was decided in the next step of the DMAIC cycle to analyze the results of galvanized wire diameter measurements using SPC type methods: control charts and process capability indicators.

\section{M - Measure}

To assess the stability of the galvanized steel production process, $\mathrm{X}$-bar and $\mathrm{R}$ charts were used. After the galvanizing process, wire samples were taken, on the basis of which the diameter was measured. The applied norm defines the diameter of the wire with a nominal value of $X_{\text {nom }}=3.00 \mathrm{~mm}$, within the tolerances of: the lower one $-\mathrm{LSL}=$ $2.97 \mathrm{~mm}$ and upper - USL $=3.08 \mathrm{~mm}$. The measurements were carried out on 25 samples taken every $1 \mathrm{~h}$, and 3 checks were carried out in each of them $\left(X_{1}, X_{2}, X_{3}\right)$. The production process of galvanized wire is subject to the action of many uncontrolled factors, which mean that not every wire has a diameter of exactly $3.00 \mathrm{~mm}$. To assess the behavior of the studied process and the degree of its predictability, a X-bar and $\mathrm{R}$ charts were used (Fig. 2).
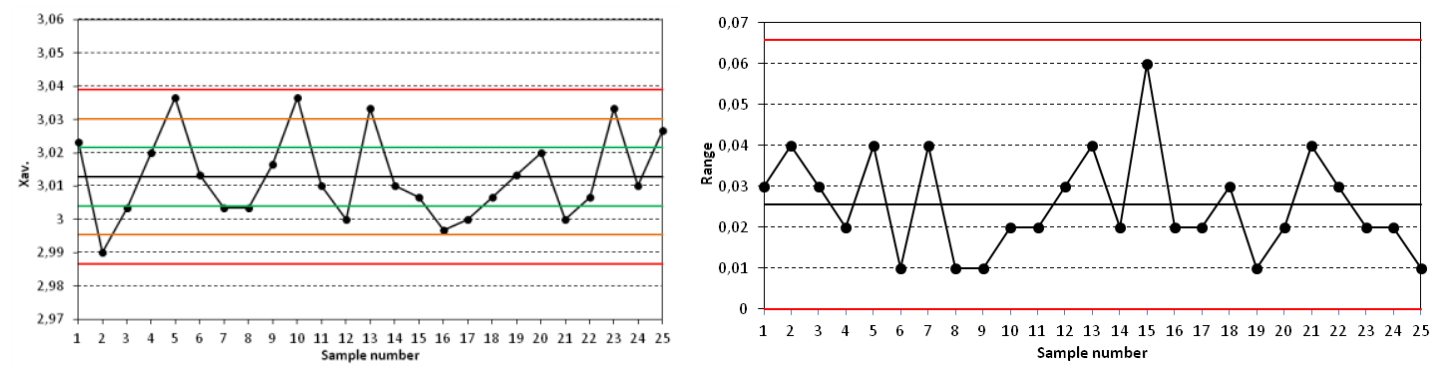

Fig. 2. $\mathrm{X}_{\mathrm{av}}-\mathrm{R}$ control chart

It was noted that in the points system on the X-bar chart there are no points beyond the control limits. In addition, the run tests (configuration tests) showed that there are no other point locations (verification of 7 different locations), which would also indicate (potential) deregulation of the process. The qualitative capability indicators were then calculated. Due to the fact that the target value of 3.00 diameters does not coincide with the middle of the specification range, the capability indicators for asymmetrical processes: $\mathrm{C}_{\mathrm{pm}}$ i $\mathrm{C}_{\mathrm{pmk}}$ were used.

$$
\begin{gathered}
C p m=\frac{U S L-L S L}{6 \sqrt{\delta^{2}+(\bar{x}-W D)^{2}}}=0,925 \\
C p m k_{d}=\frac{\overline{\bar{x}}-L S L}{3 \sqrt{\delta^{2}+(\bar{x}-W D)^{2}}}=0,720 \quad \text { (2) } \quad C p m k_{g}=\frac{U S L-\overline{\bar{x}}}{3 \sqrt{\delta^{2}+(\bar{x}-W D)^{2}}=1,131} \\
C p m k=\min \left\{C p m k_{d} ; C p m k_{g}\right\}=0,720
\end{gathered}
$$

The location of the tested process against the background of tolerance limits is shown in Fig. 3. 


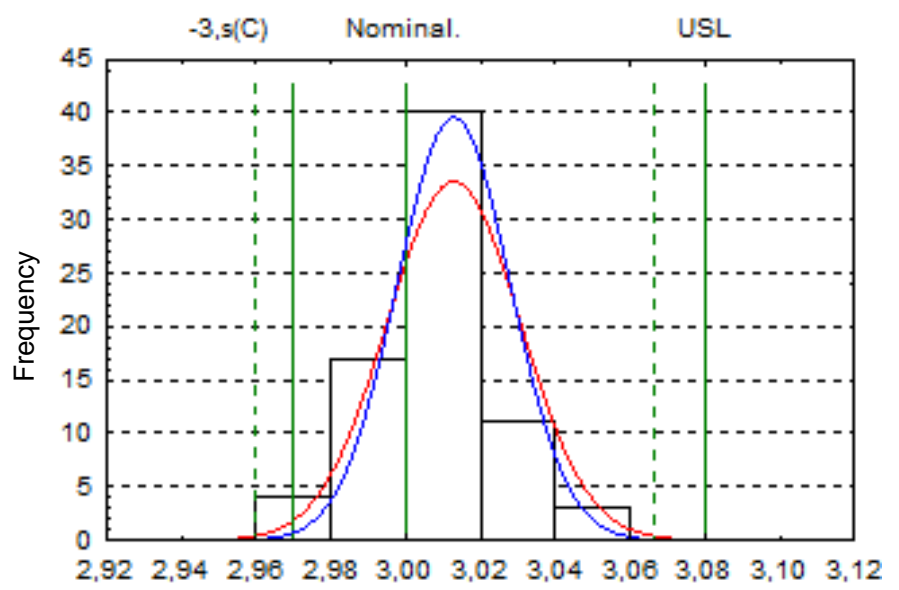

Fig. 3. Location and dispersion of the tested process against the background of tolerance limits

As results from the analyzes carried out, the level of the process's qualitative capability can not be considered satisfactory because the value of the both capacity indicators is less than 0 . Action is necessary to reduce the value of the diameter scatter. Centering the process will also improve its qualitative capability.

\section{A - Analyse}

In the next step of the DMAIC cycle, a cause-and-effect analysis was made to find potential reasons for the emergence of critical incompatibility. For this purpose, the tree form was used, where the given cause was related to the given category 4M (Machine, Man, Method, Material).

Table 2

Cause and effect analysis of the emergence of critical nonconformity

\begin{tabular}{|c|c|c|c|}
\hline $\begin{array}{c}\text { Critical } \\
\text { nonconformity }\end{array}$ & Effcect & Causes & Category \\
\hline \multirow{5}{*}{$\begin{array}{l}\text { Exceeding the } \\
\text { diameter } \\
\text { deviations of } \\
\text { the galvanized } \\
\text { wire }\end{array}$} & \multirow{5}{*}{$\begin{array}{l}\text { The diameter of } \\
\text { the galvanized } \\
\text { wire does not fit } \\
\text { into the } \\
\text { dimensional } \\
\text { tolerance range, } \\
\text { therefore the } \\
\text { finished product } \\
\text { has to wait for a } \\
\text { new customer's } \\
\text { order with exactly } \\
\text { this diameter }\end{array}$} & $\begin{array}{l}\text { Employee - operator incorrectly set the } \\
\text { galvanizing unit }\end{array}$ & Man \\
\hline & & $\begin{array}{l}\text { Employee - the operator set the wire } \\
\text { drawing machine wrong }\end{array}$ & Man \\
\hline & & $\begin{array}{l}\text { Improper interpretation of technical } \\
\text { documentation by the employee - the } \\
\text { operator }\end{array}$ & Man \\
\hline & & $\begin{array}{l}\text { Improper interpretation of quality } \\
\text { control requirements - measurement in } \\
\text { less than three locations of the wire } \\
\text { circle or less than } 2 \mathrm{~m} \text { from the end of } \\
\text { the wire } \\
\text { A little precise quality control } \\
\text { instruction }\end{array}$ & Method \\
\hline & & $\begin{array}{l}\text { Worn wire drawing } \\
\text { Lack of periodic control of the } \\
\text { technical state of the wire drawing } \\
\text { machine and/or the galvanizing } \\
\text { machine by the maintenance worker } \\
\text { and operator worker }\end{array}$ & $\begin{array}{l}\text { Machine } \\
\text { Man }\end{array}$ \\
\hline
\end{tabular}




\begin{tabular}{|l|l|l|l|}
\hline & $\begin{array}{l}\text { Lack of control of the cleanliness of } \\
\text { the dies by the employee - operator }\end{array}$ & Man \\
\hline
\end{tabular}

As can be seen from the analysis, most of the causes of non-compliance are related to the "man" category. It was decided to use the 5WHY analysis to look for the root cause of the problem. As part of the team appointed, three most probable causes of dimensional non-compliance were identified, they were verified, and then corrective action was proposed (step "I"). The results of the $5 \mathrm{WHY}$ analysis are presented in Table 3.

Table 3

$5 \mathrm{WHY}$ analysis

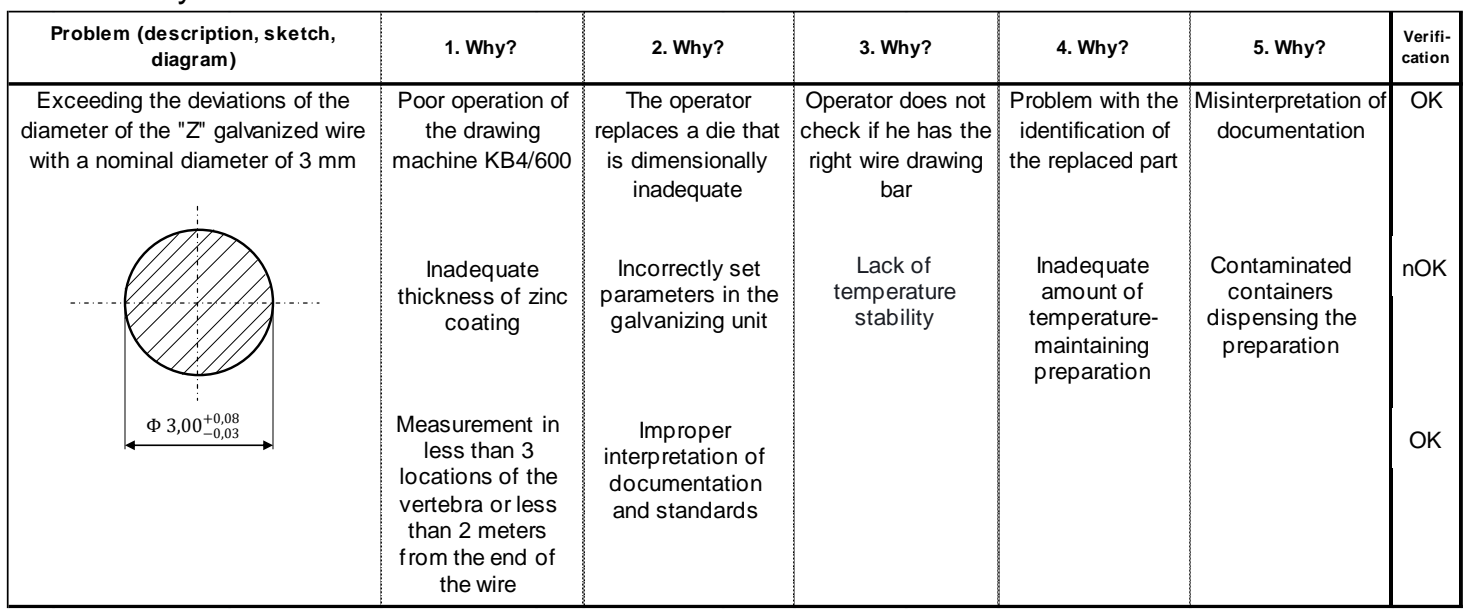

\section{I - Improve}

The source of the problem was polluted containers dispensing the preparation maintaining the temperature in the galvanizing aggregate. To eliminate the problem, it was decided to carry out the maintenance of the machine used to cover the bare wires with zinc. This activity was also included in the service schedule, because standardization of activities is the basis for improvement (Jagusiak-Kocik, 2014). The maintenance workers were also trained in the proper maintenance and cleaning of the galvanizing unit.

\section{C - Control}

After the implementation of the target activities, the following results were noted: stoppages at the Faculty of Wire Drawing and Galvanizing were eliminated, the duration of the manufacturing process was reduced, and the diameter of the finished product was within the tolerance limits. After a second analysis of the process's capability, the indexes were restored to values above $1\left(C_{m p}=1.36, C_{m p k}=1.32\right)$.

\section{CONCLUSIONS}

The article presents a case study of improving the galvanized wire production process, where the Six Sigma DMAIC cycle was used as a tool for improvement. As part of the DMAIC cycle, on each of its steps, selected methods and tools of data analysis were used as to facilitate the recognition of the source cause and the solution to the problem. This was achieved thanks to patient data analysis and teamwork of specialists who know the process and its problems. The source cause was identified, 
which was contaminated containers dispensing the preparation maintaining the temperature in the galvanizing unit, due to the lack of maintenance and cleaning of the device by maintenance workers. As part of the remedial actions, the temporary operation was to carry out maintenance and cleaning of containers, while the target action relied on modification the schedule of service works, increased the frequency of machine inspections and training of maintenance workers and operators in the area of maintenance and cleaning of the device. The implemented activities have brought the intended effect - it managed to solve the quality problem and increase the quality of the process. The DMAIC cycle has enabled objective, factual assessment and in-depth understanding of the analysed problem based on real data and the introduction of necessary changes in order to improve the functioning of the wire production process.

\section{REFERENCES}

Basu, R., Wright, J., 2003. Quality Beyond Six Sigma. Butterworth-Heinemann, Oxford. Breyfogle, F. W., 1999. Implementing Six Sigma: Smarter Solutions Using Statistical Methods. Wiley \& Sons, New York.

Chinvigai, Ch., Dafaoui, El-M. El Mhamedi, A., 2007. An approach for enhancing process and process interaction capability, 19th International Conference on Production Research.

Dziuba, ST., Ingaldi, M., Kadlubek, M., 2016. Use of quality management tools for evaluation of the products' quality in global economy, 16th International Scientific Conference on Globalization and its Socio-Economic Consequences, Rajecke Teplice, University of Zilina, 425-432.

Dziuba, ST., Ingaldi, M., Kadlubek, M., 2018. Quality analysis of the steel bars in chosen metallurgical enterprise, 27th International Conference on Metallurgy and Materials (METAL 2018), Ostrava, Tanger, 1893-1898.

Harry, M., Schroeder, R., 2005. Six Sigma - using the quality program to improve financial results [in Polish]. Oficyna Wolters Kluwer Business, Kraków.

Jagusiak-Kocik, M., 2014. Ensuring continuous improvement processes through standardization in the automotive company. Production Engineering Archives, 2/1, pp. 12-15. Available at: http://dx.doi.org/10.30657/pea.2014.02.04.

Jagusiak-Kocik, M., 2017. PDCA cycle as a part of continuous improvement in the production company - a case study. Production Engineering Archives, 14, pp.19-22. Available at: http://dx.doi.org/10.30657/pea.2017.14.05.

McCarty, Th., Bremer, M., Daniels, L., Gupta, P., 2004. The Six Sigma Black Belt Handbook. McGraw-Hill, New York.

Pande, P.S., Holpp, L., 2002. What is Six Sigma? McGraw-Hill Professional, New York.

Pande, P.S., Neumann, R.R., Cavanagh, R.R., 2000. The Six Sigma Way. McGrawHill, New York.

Sokovic, M., Pavletic, D., Kern Pipan, K., 2010. Quality Improvement Methodologies PDCA Cycle, RADAR Matrix, DMAIC and DFSS. Journal of Achievements in Materials and Manufacturing Engineering, 43, 1, pp. 476-483.

Shankar, R., 2009. Process Improvement Using Six Sigma: A DMAIC Guide. ASQ Quality Press, Milwaukee, Wisconsin.

Truscott, W., 2003. Six Sigma: Continual Improvement for Businesses. Butterworth Heinemann, Oxford.

Webber, L., Wallace, M., 2006. Quality Control for Dummies. John Wiley \& Sons, Inc., Hoboken, NJ, pp. 42-43. 